\title{
INTRODUCTORY REMARKS ON THE REPORTS OF STRONG-MOTION OBSERVATION IN JAPAN, WITH A SHORT REPORT ON THE STRONG-MOTION EARTHQUAKE OBSERVATION COUNCIL IN JAPAN
}

\author{
Kazuyoshi KUDO ${ }^{1}$ \\ ${ }^{1}$ Member of JAEE, Associate Professor, Earthquake Research Institute \\ Tokyo, Japan kudo@eri.u-tokyo.ac.jp
}

\begin{abstract}
The Strong-Motion Earthquake Observation Council is a consortium of many organizations involved in strong-motion observation in Japan. A short history and structure of the council is introduced along with the current activities of the council. Individual objectives and networks of strong motion observation of every organization are described in the following papers.
\end{abstract}

Key Words: strong-motion, earthquake observation, council, consortium

\section{SHORT HISTORY OF STRONG MOTION OBSERVATION IN JAPAN}

The Fukui earthquake of June 28, $1948\left(\mathrm{M}_{\mathrm{JMA}}\right.$ 7.1) caused catastrophic damage to houses and casualties of 3,769 in and around the city of Fukui, central Japan. However, no strong-motion record was retrieved because a strong-motion recorder had not yet been developed in Japan. Reflecting on this, seismologists and earthquake engineers developed the engineering-oriented strong-motion accelerograph (Takahashi, 1953) and established the Strong-Motion Accelerometer Committee in the Earthquake Research Institute, University of Tokyo, in 1956. The accelerograph was named SMAC, using the abbreviation of the committee. The primary type of SMAC (SMAC-A) was large and heavy (300 kg), so that efforts have been taken to manufacture more conventional types, such as SMAC-B, SMAC-B2, SMAC-C, SMAC-Q and others. The DC (Department of Construction) type accelerograph was also developed after SMAC-A. The committee encouraged installation of SMAC and DC types in buildings and other engineered structures, and occasionally made recommendations to the government to promote the development of strong-motion instrumentation. A steady increase of instrumentation of SMAC and DC types is found after the 1964 Niigata earthquake, and a decrease of SMAC after around 1980, when digital accelerographs have mostly been installed instead (Watanabe, 1993). Roughly, the total number of instruments before the 1995 Hyogo-ken Nanbu (Kobe) earthquake was about 2,000. The committee published the Strong-Motion Earthquake Records annually in Japan and the registered station table since 1964.

Along with the increasing installation of SMAC, the committee was reorganized into the Strong-Motion Earthquake Observation Council (SMEOC) in 1967, in order to encourage wider participation with strong-motion instrumentation and usage of those records for engineering / seismological applications. The SMEOC is a consortium that has been established by inviting mostly national organizations (see Table 1) that have contributed to the installation and maintenance of 
strong-motion observation in Japan. The secretariat was organized in the National Research Institute for Earth Science and Disaster Prevention (NIED). The major objectives of the SMEOC are to promote an expansion of the network of strong-motion instrumentation in Japan and to encourage variable uses of the strong-motion recordings for understanding the nature of strong-motion and for developing the technology of earthquake-resistant buildings and structures. SMEOC has succeeded in publishing the annual report in printed matter form until Vol. 40 in 1999. The Prompt Reports on Strong-Motion Accelerograms have also been published when a higher intensity of 5 by the JMA intensity scale is reported during an earthquake. The annual reports, as well as the prompt report, have appeared on the web page (http://www.k-net.bosai.go.jp/KYOUKAN/index/nenpo.htm) since 2000.

Table 1. Institutional or organizational members of SMEOC in 2004.

\begin{tabular}{|c|c|c|}
\hline Name of Institution/ Organization & Abbreviation & Related URL \\
\hline $\begin{array}{l}\text { National Research Institute for Earth } \\
\text { Science and Disaster Prevention }\end{array}$ & NIED & $\begin{array}{l}\text { http://www.k-net.bosai.go.jp/k-net/ } \\
\text { http://www.kik.bosai.go.jp/ }\end{array}$ \\
\hline Japan Meteorological Agency & JMA & $\begin{array}{l}\text { http://www.seisvol.kishou.go.jp/eq/ } \\
\text { kyoshin/index.htm }\end{array}$ \\
\hline Building Research Institute & BRI & http://iisee.kenken.go.jp/smo/ \\
\hline Port and Airport Research Institute & PARI & http://www.eq.ysk.nilim.go.jp \\
\hline $\begin{array}{l}\text { National Institute for Land and } \\
\text { Infrastructure Management }\end{array}$ & NILIM & $\begin{array}{l}\text { http://www.nilim.go.jp/japanese/ } \\
\text { database/nwdb/index.htm }\end{array}$ \\
\hline National Institute for Rural Engineering & NIRE & $\begin{array}{l}\text { http://www.nkk.affrc.go.jp/kikou/01/ } \\
\text { 01_03/01_03.htm }\end{array}$ \\
\hline $\begin{array}{l}\text { Earthquake Research Institute, University } \\
\text { of Tokyo }\end{array}$ & ERI & http://kyoshin.eri.u-tokyo.ac.jp/SMAD/ \\
\hline $\begin{array}{l}\text { Central Research Institute of Electric Power } \\
\text { Industry }\end{array}$ & CRIEPI & http://criepi.denken.or.jp/en/ \\
\hline Railway Technical Research Institute & RTRI & $\begin{array}{l}\text { http://www.rtri.or.jp/rd/openpublic/rd46/rd46 } \\
\text { 40/erthq_index.html }\end{array}$ \\
\hline NTT Group (Building Technology Institute) & NTT & http://www.ntt-bti.co.jp/quake/ \\
\hline $\begin{array}{l}\text { SUPer-dense REaltime Monitoring of } \\
\text { Earthquake, Tokyo GAS }\end{array}$ & Tokyo GAS & $\begin{array}{l}\text { http://www.tokyo-gas.co.jp/supreme/index.h } \\
\text { tml }\end{array}$ \\
\hline $\begin{array}{l}\text { The Committee of Earthquake Observation and } \\
\text { Research in the Kansai Area }\end{array}$ & CEOREKA & http://www.ceorka.org/ \\
\hline Tokyo Institute of Technology & T. I. Tech & $\begin{array}{l}\text { http://www.enveng.titech.ac.jp/info-e/ } \\
\text { res-e.html }\end{array}$ \\
\hline Fire and Disaster Management Agency & FDMA & http://www.fdma.go.jp/ \\
\hline $\begin{array}{l}\text { Emergency Management Office, City of } \\
\text { Yokohama }\end{array}$ & Yokohama & $\begin{array}{l}\text { http://www.city.yokohama.jp/me/bousai/jisin } \\
\text { _data/index.html }\end{array}$ \\
\hline $\begin{array}{l}\text { Institute of Civil Engineering of Tokyo } \\
\text { Metropolitan Government }\end{array}$ & I.C.E. TMG & $\begin{array}{l}\text { http://www.doken.metro.tokyo.jp/ } \\
\text { english/eindex.html }\end{array}$ \\
\hline The Building Center of Japan & $\mathrm{BCJ}$ & http://www.bcj.or.jp/en/index.html \\
\hline
\end{tabular}

Some remarkable new strong-motion observation networks have been established after the 1995 Hyogo-ken Nanbu (Kobe) earthquake. These are the free-field and down-hole strong-motion observation networks, the so-called K-NET and KiK-net, which are established in NIED, and the Intensity Observation Networks that is operated by JMA and the local governments all over Japan. The 
Intensity Observation Networks have the original objective to measure the seismic intensity for emergency responses of local government; as well, most intensity meters can preserve acceleration time histories. Before the Kobe earthquake, free-field strong-motion stations were very sparse and the observation sites, which were mostly in buildings/structures, were concentrated in large cities, especially in Tokyo. Another great change for the strong-motion observation community and users of strong-motion data is that K-NET and KiK-net now publish the retrieved data on the web very quickly (within a day or less), so as to let everybody use the data though the Internet.

The precise interpretations on strong-motion observation systems and/or networks that have contributed to SMEOC are presented in the following articles by the individual institutions or organizations.

\section{STRUCTURE OF SMEOC}

The board of directors consists of the representatives of member organizations of SMEOC and some researchers from academic society. The member organizations are shown in Table 1 and the representatives from these institutions and/or organizations form the Executive Committee. The secretariat of the SMEOC, funded by NIED, takes the role of administrating the meetings, arranging the data that were submitted from every organization, and maintaining the homepage mentioned above.

Fifty years has passed since the time SMAC was developed and strong-motion observation in Japan was started. SMEOC, together with JAEE, will hold the Symposium on "The 50th Anniversary of Strong-Motion Earthquake Observation in Japan -History and Perspective-“ in November 2004 at Tsukuba. The program and other details will be found in (http:// www.k-net.bosai.go.jp/ KYOUKAN/index) in the near future.

\section{SUMMARY}

This is an introductory remark on the reports from the individual institutions and organizations on their strong-motion observation systems and networks. A brief explanation on SMEOC is presented.

\section{ACKNOWLEDGMENT}

I am grateful to Prof. Yoshikazu Kitagawa, guest editor for the Special Issue, for his encouragements and to the members of the Executive Committee of SEMOC for their steady efforts and cooperation. The president of SEMOC since 2003 is Prof. Yutaka Ohta of Aichi Shukutoku University. Finally, I regret to say that Prof. Shunzo Okamoto, the first president of SEMOC, and Prof. Hiroyoshi Kobayashi, the second president of SEMOC, passed away very recently. I express my gratitude to their efforts for bringing up the SEMOC.

\section{REFERENCES}

Takahashi R. (1953). “SMAC accelerometer”, Zisin 2, 6, 117-121. (in Japanese)

Watanabe, T. (1993). "Accumulation of strong ground motion records in Japan”, in "Earthquake motion and ground conditions”, Archit. Inst. J, 527-533. 